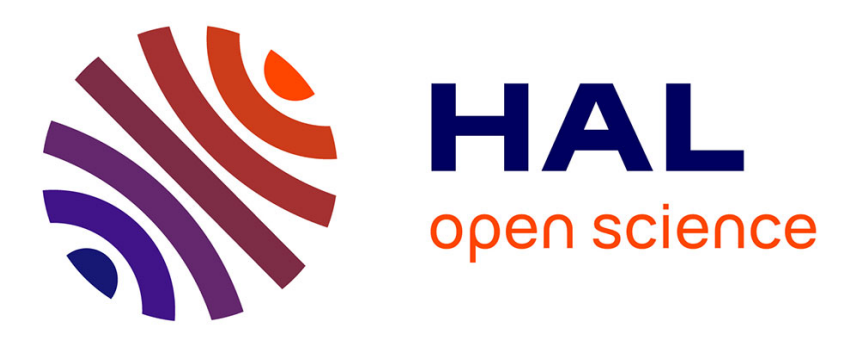

\title{
Perfume production in flowers of Angelonia salicariifolia attracts males of Euglossa annectans which do not promote pollination
}

Samuel Boff, Diego Demarco, Paola Marchi, Isabel Alves-Dos-Santos

\section{- To cite this version:}

Samuel Boff, Diego Demarco, Paola Marchi, Isabel Alves-Dos-Santos. Perfume production in flowers of Angelonia salicariifolia attracts males of Euglossa annectans which do not promote pollination. Apidologie, 2015, 46 (1), pp.84-91. 10.1007/s13592-014-0305-2 . hal-01284425

\section{HAL Id: hal-01284425 \\ https://hal.science/hal-01284425}

Submitted on 7 Mar 2016

HAL is a multi-disciplinary open access archive for the deposit and dissemination of scientific research documents, whether they are published or not. The documents may come from teaching and research institutions in France or abroad, or from public or private research centers.
L'archive ouverte pluridisciplinaire HAL, est destinée au dépôt et à la diffusion de documents scientifiques de niveau recherche, publiés ou non, émanant des établissements d'enseignement et de recherche français ou étrangers, des laboratoires publics ou privés. 


\title{
Perfume production in flowers of Angelonia salicariifolia attracts males of Euglossa annectans which do not promote pollination
}

\author{
Samuel Boff ${ }^{1,2}$, Diego Demarco ${ }^{3}$, Paola Marchi ${ }^{4}$, Isabel Alves-Dos-Santos ${ }^{4}$ \\ ${ }^{1}$ Programa de Pós-Graduação em Entomologia, Faculdade de Filosofia Ciências e Letras de Ribeirão Preto, Universidade \\ de São Paulo (USP), Av. Bandeirantes 3900, Bloco 2, Ribeirão Preto, SP 14040-901, Brazil \\ ${ }^{2}$ General Zoology, Institute for Biology, Martin-Luther-University Halle-Wittenberg, Hoher Weg 8, 06120, Halle Saale, \\ Germany \\ ${ }^{3}$ Departamento de Botânica, Instituto de Biociências, Universidade de São Paulo, São Paulo, SP 05508-090, Brazil \\ ${ }^{4}$ Departamento Ecologia, Instituto de Biociências, Universidade de São Paulo, São Paulo, SP 05508-900, Brazil
}

Received 26 November 2013 - Revised 8 April 2014 - Accepted 27 June 2014

\begin{abstract}
Male Euglossini bees (Apidae) forage for floral and non-floral perfumes. Although the use of these perfumes has not yet been clearly reported, there are indications of using perfume from varied exogenous sources as a pheromone analogue since male orchid bees do not produce it. Here, we report an interaction between male Euglossa annectans and flowers of Angelonia salicariifolia (Plantaginaceae). Floral anatomy analysis and a histological study of two different sets of trichomes indicate the presence of aromatic oils (perfume) in one set of these trichomes. The other set of trichomes produce resins. Both sets of trichomes are found in the same floral area of the flower where the male orchid bees were seen. The male orchid bees studied forage for perfumes but do not promote pollination since they do not reach the reproductive structures during their visit. Our records show that only male E. annectans were attracted to the volatile fragrance although we know that other orchid bee species also occur in the area.
\end{abstract}

\section{Euglossa annectans / Euglossini / histochemical analysis / scent robber / trichomes / volatile fragrance}

\section{INTRODUCTION}

The Euglossini, known as orchid bees, is a tribe of bees restricted to the neotropical region (Roubik and Hanson 2004), where hundreds of plant species are pollinated by both males and females (Ramírez et al. 2002; Roubik and Hanson 2004). Male orchid bees may pollinate flowers while searching for volatile fragrances, such as complex and single

Corresponding author: S. Boff,

sboff@usp.br

Handling Editor: Bernd Grünewald compounds of terpenoids and aromatic compound perfumes.

Male Euglossini bees do not produce their own pheromones; instead, they forage for perfumes. Various hypotheses have been proposed concerning the use of such volatiles. It has been suggested that the volatiles are translocated into the males' hemolymph, modified chemically and then reused as sex pheromones (Williams and Whitten 1983). Roubik and Hanson (2004) suggested that males use them for territorial defence, while Eltz et al. (2005a) showed that males can expose and relocate their fragrances during courtship display. 
Interactions between male orchid bees and flowers have been reported in several plant families, such as Araceae (Williams and Dressler 1976), Anonnaceae (Carvalho and Webber 2000), Apocynaceae, Bignoniaceae (Dressler 1982), Euphorbiaceae (Armbuster and Webster 1979), Gesneriaceae (Vogel 1966), Haemodoraceae (Dressler 1982), Solanaceae (Sazima et al. 1993) and Theaceae (Pearson and Dressler 1985), indicating that all of these flower species exhale perfume. Recently, Cappellari et al. (2009) included the family Plantaginaceae in the group of scent flowers visited by the male orchid bees. Other aromatic sources reported as perfume attractants for the Euglossini include tree trunks (Rebêlo and Garófalo 1991), rotting wood (Whitten et al. 1993), roots (Ramírez et al. 2002), fungi (Pearson and Dressler 1985; Cappellari and Harter-Marques 2010), leaf surfaces (Pemberton and Wheeler 2006) and also the hind leg of conspecific males (Carvalho Filho 2010, Pokorny et al. 2013).

The notion of a strict dependence of euglossine bees on orchids as a source of fragrances has recently been questioned on several grounds. First, it has been shown that Euglossini bees are able to forage on highly diversified fragrance sources (Ramírez et al. 2002; Roubik and Hanson 2004). Second, there is empirical evidence of at least one euglossine bee species, Euglossa viridissima, originally from Mesoamerica, thriving in the newly invaded southern USA despite the absence in this region of its mutualistic orchids (Pemberton and Wheeler 2006). Third, a study on the co-phylogeny of euglossine bees and orchids illustrated that the use of perfumes by Euglossini started ca. 12 million years before orchid diversification, suggesting that this mutualism originated as an association in which orchids took advantage of an already evolved preference in bees for certain fragrances (Ramírez et al. 2011).

The genus Angelonia (Plantanginaceae), restricted to the neotropical region, offers oil for its pollinators in differentiated structures called elaiophores (Vogel 1974). These structures, located inside the floral tube, were divided by Vogel into two distinct groups: trichromatic elaiophores (grouping of glandular hairs) and epithelial elaiophores (grouping of glandular cells covered by a thin epidermal cuticle). In flowers of Angelonia, trichomatic elaiophores are the most common type (Vogel 1974). The genus Angelonia is exclusively dependent on oil bees for pollination (Buchmann 1987). The tribes Centridini, Tapinotaspidini and Tetrapedini (Hymenoptera: Apidae) were reported as their main pollinators (Vogel and Machado 1991; Machado et al. 2002; Martins et al. 2013).

We report here the interaction between male orchid bees and flowers of Angelonia salicariifolia Humb. \& Bonpl (Plantaginaceae). The aim of this study was to understand why male orchid bees visit such species by looking for the presence of structures related with aromatic compound emission using floral anatomy and a histological approach.

\section{MATERIAL AND METHODS}

The interactions between male orchid bees and A. salicariifolia were first recorded in the field (farm of Morro do Capim, $24^{\circ} 22^{\prime} \mathrm{S}, 47^{\circ} 58^{\prime} \mathrm{W}$ ), a rural area in Sete Barras, SP, Brazil, when one individual was collected and morphologically identified as Euglossa annectans (Hymenoptera: Apidae: Euglossini) by Gabriel Melo from the Federal University of Paraná. After these observations, samples of $A$. salicariifolia were removed and planted in the garden of the Bee Lab at the University of São Paulo $\left(23^{\circ} 33^{\prime} \mathrm{S}, 46^{\circ} 43 \mathrm{~W}\right.$, ca. $200 \mathrm{~km}$ from Sete Barras). In the garden, new observations of the interaction between males of the same species and flowers were made. The foraging behaviour of these orchid bees was studied in between November to February, during the summer (wet season) of 2010, 2011 and 2012 by random direct observation between 08:00 a.m. to 04:00 p.m., as well as photography and video recording.

Samples of 15 flowers of Angelonia salicariiolia from different individuals were collected for structural analysis. The analyses were carried out using scanning electron microscopy and light microscopy. From these analyses, we identified the presence of two sets of trichomes in the flowers. The secretion produced by glandular trichomes was histochemically analysed under the following conditions: Sudan black B and Sudan IV (Pearse 1985) and neutral red (Kirk 1970) for total lipids, in visible and UV light, respectively; Nile blue 
(Cain 1947) for neutral and acidic lipids; copper acetate/ rubeanic acid (Ganter and Jollés 1969, 1970) for fatty acids; ferric chloride (Johansen 1940) and autofluorescence in UV light for phenolic compounds; Wagner's reagent (Furr and Mahlberg 1981) for alkaloids; periodic acid/Schiff's reaction (PAS) (Jensen 1962) for polysaccharides; ruthenium red (Gregory and Baas 1989) for acidic mucilage and Nadi reagent (David and Carde 1964) for terpenoids. This last reagent is able to distinguish different colour volatile oils (mono- and sesquiterpenes) from di-, tri-, and tetraterpenes and derivatives. These analyses were useful to cheque for and recognise the presence of volatile substances. All analyses of chemical compounds reported in this study were qualitative.

In parallel with our observations, in 2010 we offered in the surrounding area of the Bee Lab several synthetic orchid scents (cineole $99 \%$, eugenol $99 \%$ and beta ionone $96 \%$ ), known to be effective attractants of males from several orchid bee species in São Paulo (eg. Cordeiro et al. 2013). Around 10-15 drops of the synthetic compound were added to a cotton ball wrapped in lint and then occasionally offered in the garden near the flowering patches.

\section{RESULTS}

The structural analysis of $A$. salicariifolia flowers revealed the presence of non-glandular trichomes (Figures 1a, d and 2a) and two different types of glandular trichomes (Figure 1a-c, e-g). Throughout most of the pedicel, calyx and corolla, the trichomes are concentrated mainly on the apex of the abaxial portion of the lateral and lower lobes of the corolla (Figure 1c), the same region where the male orchid bee activity was observed (Figure 3). Some of these trichomes present a slightly different structure and their secretions display a more homogeneous and viscous appearance.

The predominant type of glandular trichome found on the flower was a digital form with a multicellular secretory head composed of narrow cells (Figures $1 \mathrm{f}$ and $2 \mathrm{~b}-\mathrm{c}$ ), producing volatile oils (perfume) found as lipid droplets in the cytoplasm (Figure 2e-g, i, k). The other type of glandular trichome is the capitated form presenting a slightly longer peduncle and occurring only on the abaxial side of sepals and apices of the petals
(Figure 2d). They present a wider secretory head composed of elongated cells producing resin observed as a homogenous lipid secretion in the cytoplasm (Figure 2h, j).

The histochemical analysis indicated that both glandular trichomes produced only lipids, but the digital form trichomes also synthesize volatile substances composed of phenolic compounds (Figure 2e) and terpenoids (Figure 2k). The tests for fatty acids, alkaloids and acidic mucilage were all negative.

From our random observations, we agreed that all the visits $(n=40)$ to the flowers made by $E$. annectans were illegitimate since the males only moved on the corolla but never touched the reproductive structures of the flowers during the visitation. The males of $E$. annectans used the middle pair of legs to hold onto the flower. After landing on the flower, they started scraping its surface using the brushes found on the tibia of the forelegs (Figure 3). Such behaviour was performed on the edges of the abaxial portion on the lateral lobe and lower lobes, where the glandular trichome in capitated form is especially concentrated.

During the visits and the collection of perfume, E. annectans males used their antennae to touch the surface of the petal, seemingly in the same place where the brushes on the tibia were being used. After leaving the flower, the males hovered in front of or around the visited flower. When they hovered, the chemical fragrances that were placed on the brushes of the first fore tibia legs were transferred to the middle and then to the hind tibia, where the content was stored in a sponge-like cavity. This behaviour was observed several times after the bee visited the same and different flowers during the same flyby. The visits were usually observed on warm days starting in the morning with the last visits taking place around 04:00 p.m..

Other bee species were also observed during the study. Species of Centris (Apidae: Centridini) were observed collecting oil from the glands inside the flowers, promoting pollination since the dorsal part of the thorax touched the reproductive structures during the visits. Individuals of Tetrapedia diversipes (Apidae: Tetrapediini) were observed foraging for pollen, however, without promoting pollination. 

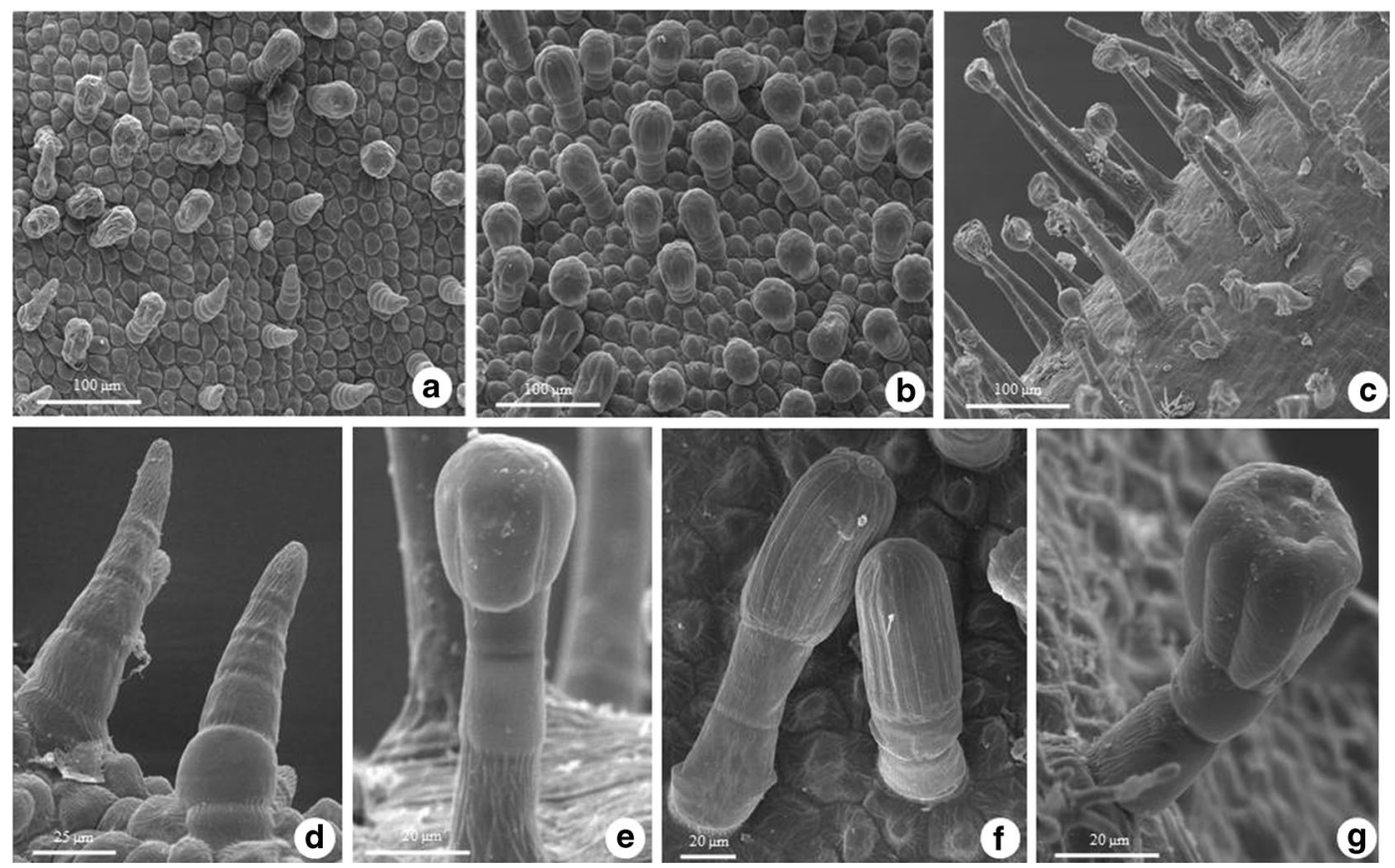

Figure 1. SEM of the petals of A.salicariifolia. a. General view of the glandular and non-glandular trichomes. b-c Glandular trichomes on petal center (b) and margin (c). d-g Details of the non-glandular (d) and glandular trichomes on the petal centre (e-f) and margin (g).

When synthetic compounds similar to orchid scents were provided in the study area, Eg. annectans as well as other orchid bees species, such as Eufriesea violacea and Eulaema nigrita, were attracted, indicating the presence of other Euglossini species in the study area. However, these species were not observed visiting flowers of $A$. salicariifolia.

\section{DISCUSSION}

The digital form trichomes produce volatile oils, histochemically identified as phenolic compounds and essential oils (terpenoids). The digital trichome was observed to be widespread on the flower, and its volatile secretion might attract $E$. annectans, although the human sense of smell is not able to detect this perfume. Floral fragrance trichomes are rare and usually emit a weak odour, but the indistinct perfume becomes more perceptible if accumulated on a glass tube, as done for Phragmopedilum grande (Vogel 1990).

The capitate trichomes from the studied plants are restricted to the place where bees were observed foraging in the flowers. The secretion of these trichomes is composed of viscous aromatic substances and probably less related with the attraction of the orchid bees observed. It is known that these viscous aromatic substances are composed of di-, tri- and tetraterpenes, which when combined are viscous and non-volatile (Buchanan et al. 2000; Langenheim 2003), like resin acids (David and Carde 1964). A mixture of both seems to occur in the secretion of the capitate trichomes and probably is only slightly or non-volatile.

Although both trichomes produce aromatic substances, depending on the carbon chain size of the terpenoid molecule, it may be more or less viscous and volatile (Langenheim 2003). Only terpenes with low molecular weight can volatilize and pass through both cell wall and cuticle (Vogel 1990). Monoterpenes and sesquiterpenes (essential oils) are volatile (Langenheim 2003), constituting the main component of secretions related to the attraction of pollinators (Vogel 1990; Buchanan et al. 2000), and turn blue with Nadi reagent (David and Carde 1964), as observed here in the digital form trichomes of $A$. salicariifolia. 


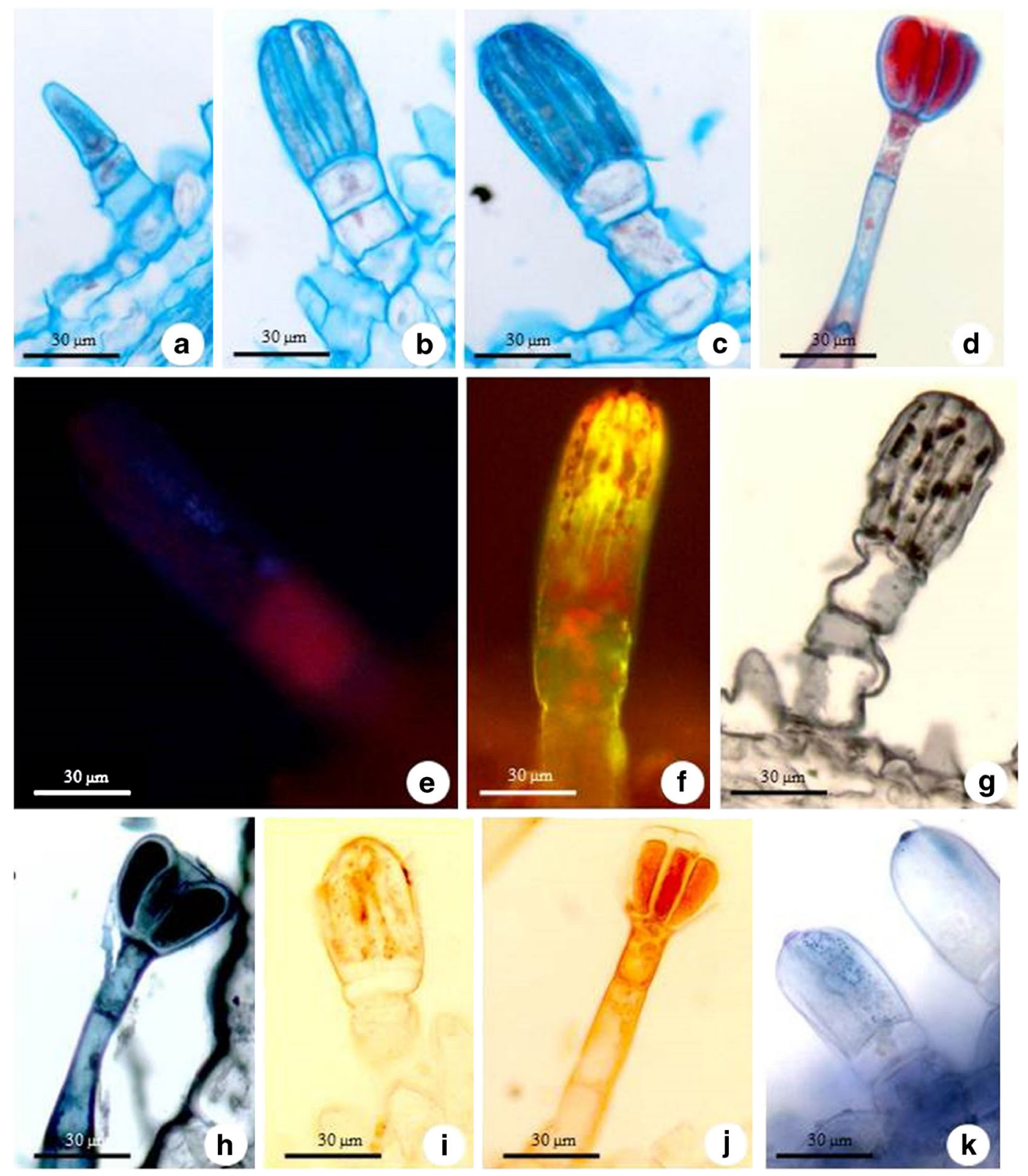

Figure 2. Structure and histochemistry of the petal trichomes of $A$. salicariifolia. $\mathbf{a}$. Non-glandular trichome. b-c Glandular trichomes on the petal centre. d Glandular trichome of the petal margin. e Autofluorescence of phenolic compounds (blue). $\mathbf{f}-\mathbf{j}$ Detection of lipids with neutral red (f), Sudan black B (g-h), and Sudan IV (i-j). k Detection of essential oils with Nadi reagent.

Based on the foraging behaviour in the present study, we did not find evidence that males of E. annectans are pollinators of A. salicariifollia but act as aromatic scent robbers. Although the collection of perfume in the flowers of $A$. salicariifolia can be recognised based on post-foraging behaviour and the description of perfume collection in 


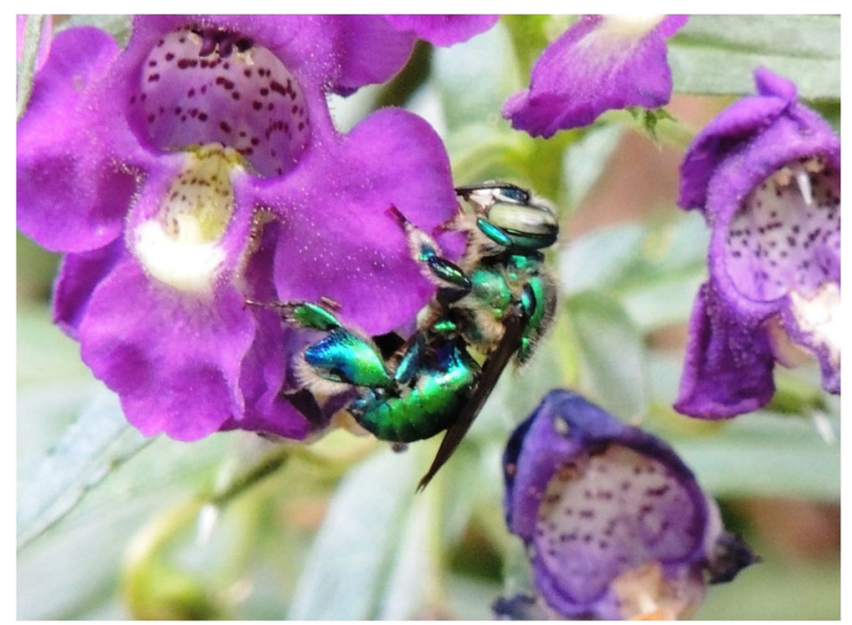

Figure 3. Male of Euglossa annectans foraging for aromatic oil located in the trichomes on the lateral lobes of the petals of Angelonia salicariifolia (Photo: Paulo Cesar Fernandes).

previous studies (Dodson et al. 1969; Dressler 1982), we cannot exclude the foraging for lipids from the glandular trichomes since both trichomes types are distributed on the same petal lobe region. Our findings reinforce the hypothesis raised by Cappellari et al. (2009) that the use of such lipids could prevent the loss of perfume through evaporation. This idea concurs with that of Eltz et al. (2008), who stated that some orchid bees have quite an efficient mechanism of using and recycling lipids to dissolve the volatiles to accumulate and concentrate their perfume.

The foraging behaviour of Euglossini in flowers of Plantaginaceae species was first mentioned for Euglossa mandibularis in flowers of Mercadonia tenellus in southern Brazil (Cappellari et al. 2009). However, unlike $A$. salicariifolia, a species pollinated exclusively by oil bees (Martins et al. 2013), M. tenellus cannot clearly be associated with one particular pollination syndrome since multiple visitors, including male orchid bees, pollinate the flowers, resulting in a mutual benefit (Cappellari et al. 2009). In the present study, the interaction seems to be advantageous only for E. annectans males since the flowers do not seem to be pollinated by them.

The presence of other orchid bee species in the studies areas, University of São Paulo (Alves dos Santos, unpubl. data.) and Sete Barras (Matozzo et al. 2011), may be evidence of a specific attractiveness by $E$. annectans to one specific aromatic compound found in the perfume of A. salicariifolia since the volatile compound does not attract other orchid bee species. This finding reinforces the idea that Euglossini are generalists regarding the available source (floral or non-floral source), but some species may be specialists regarding the kind of perfume they are attracted to or forage. Recently, Pokorny et al. (2013) reported by means of perfume attraction assays that two species of Euglossa reacted differently to specific extract compounds. The experiments showed that only co-specific males were attracted when those volatiles were offered. Other studies have also suggested a preference for some specific fragrance compounds, predicting in this case speciesspecific interactions between euglossine bee species and plant species (Eltz et al. 2005b, 2008).

Though pollination syndromes are questioned (Waser et al. 1996; Smith et al. 2009), there have been studies that highlight their verity (Faegri and van der Pijl 1979, Rosas-Guerrero et al. 2014). For example, the floral features of $A$. salicariifolia appropriately match the pollination syndrome of oil-collecting Centridini bees (Martins et al. 2013). Although modification of flower structures lead to a pollinator shift (Peter and Johnson 2014, Cappellari et al. 2011), the current data are insufficient to discriminate a possible case of pollinator 
shift since the trichomes related to volatile production are mainly in the lobe of the corolla and the orchid bees do not even touch the reproductive structures of the plant during the visits.

We observed that pollinators (Centris spp.) visit flowers previously visited by the orchid bee, meaning that previous visits of E. annectans probably did not make the flower unviable to be pollinated. Thus, we raise the hypothesis that the previous visits by $E$. annectans do not disturb the interaction between the same flower and the main pollinator, meaning that the orchid bee does not affect the reproduction of the $A$. salicariifolia, nor is it a competitor with the pollinator since they forage different sources.

\section{ACKNOWLEDGMENTS}

We thank Claudia Saito and Sheina Koffler for their help and additional observations in the field, Paulo César Fernandes for providing pictures and Antonella Soro and the two reviewers for helpful comments. Coordenação de Aperfeiçoamento de Pessoal de Nível Superior (CAPES) funded the first author.

La production de parfum dans les fleurs d'Angelonia salicariifolia attire les mâles d'Euglossa annectans bien qu'ils ne participent pas à la pollinisation

Euglossini / analyse histochimique / voleur de parfum / trichomes / parfum volatile

Duftproduktion in Blüten von Angelonia salicariifolia wirken anziehend auf Männchen von Euglossa annectans, die nicht als Bestäuber fungieren

Euglossa annectans / Euglossini / histochemische Analyse / Duft Räuber / Trichom / flüchtige Duftstoffe

\section{REFERENCES}

Armbuster, W.S., Webster, G.L. (1979) Pollination of two species of Dalechampia (Euphorbiaceae) in Mexico by euglossine bees. Biotropica 11, 278-283

Buchanan, B.B., Gruissem, W., Jones, R.L. (2000) Biochemistry and molecular biology of plants. American Society of Plant Physiologists, Rockville
Buchmann, S. (1987) The ecology of oil flowers and their bees. Annu Rev Ecol Syst 18, 343-369

Cain, A.J. (1947) The use of Nile blue in the examination of lipoids. Q J Microsc Sci 88, 383-392

Cappellari, S.C., Harter-Marques, B. (2010) First report of scent collection by male orchid bees (Hymenoptera: Apidae: Euglossini) from terrestrial mushrooms. J Kansas Entomol Soc 83, 264-266

Cappellari, S.C., Harter-Marques, B., Aumeier, P., Engels, W. (2009) Mercadomia tenella (Plantaginaceae) attracts oil-, perfume-, and pollen-gathering bees in Southern Brazil. Biotropica 41, 721-729

Cappellari, S.C., Haleem, M.A., Marsaioli, A.J., Tidon, R., Simpson, B.B. (2011) Pterandra pyroidea: a case of pollination shift within Neotropical Malighiaceae. Ann Bot-London 107, 1323-1334

Carvalho Filho, F.S. (2010) Scent-robbing and fighting among male orchid bees, Eulaema (Apeulaema) nigrita Lepeletier, 1841 (Hymenoptera: Apidae: Euglossini). Biota Neotrop 10, 405-408

Carvalho, R., Webber, A.C. (2000) Biologia floral de Unonopsis guatterioides (A.D.C.) R.E. Fr., uma Annonaceae polinizada por Euglossini. Revta bras Bot 23, 421-425

Cordeiro, G.D., Boff, S., Caetano, T.A., Fernandes, P.C., Alves dos Santos, I. (2013) Euglossine bees (Apidae) in Atlantic forest areas of São Paulo State, southeastern Brazil. Apidologie 44, 254-267

David, R., Carde, J.P. (1964) Coloration différentielle des inclusions lipidique et terpeniques des pseudophylles du Pin maritime au moyen du reactif Nadi. C R Acad Sci (Paris) 258, 1338-1340

Dodson, C.H., Dressler, R.L., Hills, H.G., Adams, R.M., Williams, N.H. (1969) Biologically active compounds in orchid fragrances. Science 164, 1243-1249

Dressler, R.L. (1982) Biology of the orchid bees (Euglossini). Annu Rev Ecol Syst 13, 373-394

Eltz, T., Roubik, D.W., Lunau, K. (2005a) Experiencedependent choices ensure species-specific fragrance accumulation in male orchid bee. Behav Ecol Sociobiol 59, 129-156

Eltz, T., Sager, A., Lunau, K. (2005b) Juggling with volatiles: exposure of perfumes by displaying male orchid bees. J Comp Physiol 191, 575-581

Eltz, T., Zimmermann, Y., Pfeiffer, C., Ramírez Pech, J., Twele, R., Francke, W., Quezada-Euan, J.J.G., Lunau, K. (2008) An olfactory shift is associated with male perfume differentiation and species divergence in orchid bees. Curr Biol 18, 1844-1848

Faegri, K., van der Pijl, L. (1979) The principles of pollination ecology, 3rd revised edition. Pergamon Press, Oxford

Furr, M., Mahlberg, P.G. (1981) Histochemical analyses of laticifers and glandular trichomes in Cannabis sativa. $\mathrm{J}$ Nat Prod 44, 153-159

Ganter, P., Jollés, G. (1969) Histologie normale et pathologique, vol. 1. Gauthier-Villars, Paris 
Ganter, P., Jollés, G. (1970) Histologie normale et pathologique, vol. 2. Gauthier-Villars, Paris

Gregory, M., Baas, P. (1989) A survey of mucilage cells in vegetative organs of the dicotyledons. Isr J Bot 38, 125-174

Jensen, W.A. (1962) Botanical histochemistry: principles and practice. Freeman, San Francisco

Johansen, D.A. (1940) Plant microtechnique. McGrawHill, New York

Kirk Jr., P.W. (1970) Neutral red as a lipid fluorochrome. Stain Technol 45, 1-4

Langenheim, J.H. (2003) Plant resins: chemistry, evolution, ecology, and ethnobotany. Timber Press, Cambridge

Machado, I.C., Vogel, S., Lopes, A.V. (2002) Pollination of Angelonia cornigera Hook. (Scrophulariaceae) by long-legged, oil collecting bees in NE Brazil. Plant Biol 4, 352-359

Martins, A.C., Aguiar, A.J.C., Alves dos Santos, I. (2013) Interaction between oil-collecting bees and seven species of Plantaginaceae. Flora 208, 401-411

Matozzo, V.C., Faria, L.R.R., Melo, G.A.R. (2011) Orchid bees (Hymenoptera: Apidae) in the coastal forest of southern Brazil: diversity, efficiency of sampling methods and comparison with other Atlantic forest surveys. Pap Avulsos Zool 51, 505-515

Pearse, A.G.E. (1985) Histochemistry: theoretical and applied, vol. 2. 4th ed. C. Livingstone, Edinburgh

Pearson, D.L., Dressler, R.L. (1985) Two-year study of male orchid bee (Hymenoptera: Apidae: Euglossini) attraction to chemical baits in lowland southeastern Peru. J Trop Ecol 1, 37-54

Pemberton, R.W., Wheeler, G.S. (2006) Orchid bees don't need orchids: evidence from the naturalization of an orchid bee in Florida. Ecology 87, 1995-2001

Peter, C.I., Johnson, S.D. (2014) A pollinator shift explains floral divergence in an orchid species complex in South Africa. Ann Bot-London 113, 277-288

Pokorny, T., Hannibal, M., Quezada-Euan, J.J.G., Hedenström, E., Sjöberg, N., Bång, J., Eltz, T. (2013) Acquisition of species-specific perfume blends: influence of habitat-dependent compound availability on odour choices of male orchid bees (Euglossa spp.). Oecologia 172, 417-425

Ramírez, S., Dressler, R.L., Opsina, M. (2002) Abejas euglossinas (Hymenoptera:Apidae) de la Región Neotropical: Listado de espeices con notea sobre su biología. Biot Colomb 3, 7-118
Ramírez, S., Eltz, T., Fujiwara, M.K., Gerlach, G., Goldman-Huertas, B., Tsutsui, N.D., Pierce, N.E. (2011) Asynchronous diversification in a specialized plant-pollinator mutualism. Science 333, 1742-1746

Rebêlo, J.M.M., Garófalo, C.A. (1991) Diversidade e sazonalidade de machos de Euglossini (Hymenoptera, Apidae) e preferências por iscasodores em um fragmento de floresta no sudeste do Brasil. Rev Bras Biol 51, 787-799

Rosas-Guerrero, V., Aguilar, R., Martén-Rodríguez, S., Ashworth, L., Lopezaraiza-Mikel, M., Bastida, J.M., Quesada, M. (2014) A quantative review of pollination syndrome: do floral traits predict effective pollinators? Ecol Lett 17, 388-400

Roubik, D.W., Hanson, P.E. (2004) Abejas de orquídeas de a América tropical: biologia y guia de campo. Orchid bees of tropical America: biology and field guide, San José

Sazima, M., Vogel, S., Cocucci, A., Hausner, G. (1993) The perfume flowers of Cyphomandra (Solanaceae): pollination by euglossine bees, bellows mechanism, osmophores, and volatiles. Plant Syst Evol 187, 51-88

Smith, S.D., Ané, C., Baum, D.A. (2009) Macroevolutionary tests of pollination syndromes: a reply to Fenster et al. Evolution 63, 2763-2767

Vogel, S. (1966) Parfümsammelnde Bienen als Bestäuber von Orchidaceen und Gloxinia Osterr. Bot Zs 113, 302-361

Vogel, S. (1974) Ölblumen und ölsammelnde Bienen. Trop Subtrop Pflanzenwelt 7, 1-267

Vogel, S. (1990) The role of scent glands in pollination. Amerind Publishing, New Delhi

Vogel, S., Machado, I.C. (1991) Pollination of four sympatric species of Angelonia (Scrophulariaceae) by oilcollecting bees in NE Brazil. Plant Syst Evol 178, 153178

Waser, N.M., Chittka, L., Price, M.V., Williams, N.M., Ollerton, J. (1996) Generalization in pollination systems, and why it matters. Ecology 77, 1043-1060

Whitten, W.M., Young, A.M., Stern, D.L. (1993) Nonfloral sources of chemicals that attract male euglossine bees (Apidae: Euglossini). J Chem Ecol 19, 30173027

Williams, N.H., Dressler, R.L. (1976) Euglossine pollination of Spathiphyllum (Araceae). Selbyana 1, 349-356

Williams, N.H., Whitten, W.M. (1983) Orchid floral fragrances and male Euglossine bees: methods advances in the last sesquidecade. Biol Bull 164, 355-395 